\title{
Bioerosion and fungal colonization of the invasive foraminiferan Amphistegina lobifera in a Mediterranean seagrass meadow
}

\author{
Martin Vohník \\ Department of Mycorrhizal Symbioses, Institute of Botany, Czech Academy of Sciences, Průhonice, 25243, Czechia
}

Correspondence: Martin Vohník (vohnik@ibot.cas.cz)

Received: 2 December 2020 - Discussion started: 8 January 2021

Revised: 15 March 2021 - Accepted: 16 March 2021 - Published: 30 April 2021

\begin{abstract}
Foraminiferans are diverse micro- to macroscopic protists abundant especially in (sub)tropical seas, often forming characteristic benthic communities known as "living sands". Numerous species have migrated through the Suez Canal to the Mediterranean and one of them, i.e., Amphistegina lobifera, turned invasive, gradually outcompeting the indigenous species. At some places, A. lobifera creates thick seabed sediments, thus becoming an important environmental engineer. However, little is known about the turnover of its shells in the invaded ecosystems. Using vital staining, stereomicroscopy, scanning electron microscopy, and cultivation and DNA fingerprinting, I investigated the vital status, destruction/decomposition and mycobiota of A. lobifera in the rhizosphere of the dominant Mediterranean seagrass Posidonia oceanica in an underwater Maltese meadow (average 284 shells $\mathrm{g}^{-1}$, representing $28.5 \%$ of dry substrate weight), in comparison with epiphytic specimens and P. oceanica roots. While $78 \%$ of the epiphytes were alive, nearly all substrate specimens were dead. On average, $80 \%$ of the epiphytes were intact compared to $21 \%$ of the substrate specimens. Abiotic dissolution and mechanical damage played only a minor role, but some bioerosion was detected in $18 \%$ and $>70 \%$ of the epiphytic and substrate specimens, respectively. Few bioerosion traces could be attributed to fungi, and the majority probably belonged to photoautotrophs. The seagrass roots displayed fungal colonization typical for this species and yielded 81 identified isolates, while the surface-sterilized substrate specimens surprisingly yielded no cultivable fungi compared to 16 other identified isolates obtained from the epiphytes. While the epiphytes' mycobiota was dominated by ascomycetous generalists also known from terrestrial ecosystems (alongside with, for example, a relative of the "rock-eating" extremophiles), the
\end{abstract}

roots were dominated by the seagrass-specific dark septate endophyte Posidoniomyces atricolor and additionally contained a previously unreported lulworthioid mycobiont. In conclusion, at the investigated locality, dead A. lobifera shells seem to be regularly bioeroded by endolithic non-fungal organisms, which may counterbalance their accumulation in the seabed substrate.

\section{Introduction}

Foraminiferans or Foraminifera (i.e., forams; SAR: Rhizaria: Retaria; see Irwin et al., 2019) are amoeboid eukaryotic protists producing large networks of very thin cytoplasmic extrusions (reticulopodia) and living enclosed in genetically fixed single or multichamber tests (i.e., shells) made of various organic and inorganic materials. With several thousands of recent species, forams represent one of the most diverse groups of marine protist, being found in all marine environments from the tropics to the polar regions, from brackish to hypersaline waters and from the intertidal to the depths of the ocean trenches (Murray, 2006). Nevertheless, forams are especially abundant in tropical and subtropical seas where their tests form a principal source of calcium carbonate (Langer, 2008; Langer et al., 1997). Marine forams are planktonic and benthic; the latter group is significantly more diverse and encompasses larger symbiont-bearing forams forming specific assemblages known as "living sands" that often dominate tropical and subtropical photic seabed substrates (see Lee and Anderson, 1991, and references therein).

Many (sub)tropical foraminiferal species have been introduced from the Red Sea through the Suez Canal to the generally colder Mediterranean Sea (following the so-called 
Lessepsian route; see Galil, 2006), including several larger forams, and while some of them are rather rare, others became important benthic components dominating local foram communities and profoundly changing the structure and type of the invaded habitats, thus acting as "environmental engineers" (Langer et al., 2012; Yokeş and Meriç, 2009). Arguably the most abundant alien foram in the Mediterranean Sea is the calcareous symbiont-bearing Amphistegina lobifera (Rotaliida: Amphisteginidae, Fig. 1a-c). It is widely distributed in the eastern Mediterranean basin (Guastella et al., 2019; Langer et al., 2012), and thanks to its high dispersal potential aided by increasing water temperatures (Langer et al., 2013; Weinmann et al., 2013a, b), it gradually expands westwards, with the current distribution limit laying between the coast of southern Tunisia, the Maltese islands and the Adriatic coast along southern Albania (Yokeş et al., 2007; Langer and Mouanga, 2016; El Kateb et al., 2018). In the Levantine Basin, it often forms very dense populations resulting in seabed sediments up to $80 \mathrm{~cm}$ thick that in a way resemble the tropical living sands (Yokeş et al., 2014; Figs. 1d and $2 a)$.

While foram ecology, evolution, physiology and taxonomy have attracted significant research attention, comparably less is known about the postmortem fate of their shells or, more specifically, about the agents causing foram shell degradation/destruction during early burial (cf. Martin, 1999). The main abiotic processes (disaggregation, corrosion/dissolution, fragmentation, mechanical abrasion, transport, etc.) have been studied to a larger degree (e.g., Berger, 1967; Denne and Sen Gupta, 1989; Kotler et al., 1992; Berkeley et al., 2009; Briguglio and Hohenegger, 2011), and it is evident that they have profound selective effects on dead foram assemblages. For example, abiotic dissolution especially affects forams with smaller and calcareous tests, thus significantly modifying the composition of the foram sediment/paleoecological record ("taphonomic bias", e.g., Martin and Wright, 1988; Green et al., 1993; Murray and Alve, 1999; Nguyen et al., 2009). In contrast, the biotic processes (bioerosion, decomposition) have been studied to a lesser extent and mostly at the descriptive level (e.g., Kloos, 1982; Nielsen and Nielsen, 2001; Malumián et al., 2007; Cherchi et al., 2012; Frozza et al., 2020), despite the fact that they may cause impacts similar to the abiotic ones (cf. Perkins and Halsey, 1971) and, for example, alleviate the negative impact of the accumulation of alien foram shells in the invaded ecosystems (cf. Yokeş and Meriç, 2009).

Bioerosion can be defined as the destruction and removal of consolidated substrates (lithic and plant/woody material) by the action of organisms (Neumann, 1966; Bromley, 1992; Tribollet et al., 2011), while decomposition can be described as the breaking down of dead organic matter by the action of (micro)organisms (Kothe, 2011). Bioerosion can be divided into bioabrasion (caused by various grazers), biocorrosion (chemical attack) and boring (various macro- or microborers) (Neumann, 2008); for alternative definitions, see Brom- ley (1992) and Tribollet et al. (2011). Macro- and microborers constitute the endolithic guild of bioeroders, in general represented by soft-bodied organisms producing shallow stationary bores in hard substrates (Golubić et al., 1981; Tapanila, 2008). Microborers comprise both autotrophs (algae, cyanobacteria) and heterotrophs (bacteria, bryozoans, fungi, small sponges, etc.) (Bromley, 1992; Tapanila, 2008). With a few exceptions (like fungi seeking and utilizing organic skeletal matrix and subsequently resting in the resulting bores; see Warme, 1975), boring activities are typically connected with creating a living space/shelter in a hard substrate (Schönberg and Wisshak, 2014) while, during decomposition, the respective organisms obtain food (i.e., source of carbon, energy, etc.) from various organic substrates. For historical and practical reasons, bioerosion and decomposition have been typically studied by different research communities (paleontologists and biogeologists vs. biologists of different specializations) that use different methodological approaches (for bioerosion, see Golubić et al., 1970; Hirsch et al., 1995; Wisshak and Tapanila, 2008; Golubić et al., 2019; Heřmanová et al., 2020, and many others).

Fungi commonly colonize both abiotic and biotic (both living and dead) substrates and arguably represent the most understudied group of marine bioeroders, despite the fact that they are known from practically all marine habitats (e.g., Golubić et al., 2005; Gadd, 2011; Amend et al., 2019). While they may be the dominant microborers in the aphotic zone, they are also quite common in shallower depths where they colonize various biotic substrates like carapaces of crustaceans, shells of molluscs, submerged driftwood, thalli of calcareous algae, etc. (e.g., Kohlmeyer, 1969; Kohlmeyer et al., 2004; Golubić et al., 1975; Rämä et al., 2014, and many others). Fungal interactions with forams are not very well understood, despite the fact that the foram biomass may represent a potentially important trophic resource in many marine ecosystems (cf. Lipps, 1983; Lee and Anderson, 1991). The available literature is scarce, and most of the studies are observational and without an evidenced explanation of the nature of the observed interaction. For example, under laboratory conditions, some unidentified fungi were observed to colonize and possibly also bioerode shells of Archaias angulatus (Miliolida: Soritidae) (Butcher and Steinker, 1979). Some ascomycetous arenicolous species can colonize dead tropical forams and produce sporocarps inside and on the surface of their shells, while under laboratory conditions, the shell material may serve as a sole source of nutrients for the fruiting fungi (Kohlmeyer, 1984, 1985; VolkmannKohlmeyer and Kohlmeyer, 1993; also see Fig. 1a in Tokura, 1983). Finally, Shroba (1993) ascribed some taphonomic features observed on the shells of temperate benthic forams to fungi but without a detailed documentation and identification of the responsible microborers.

From the foram point of view, fungi are generally not considered a part of their diet (cf. Lee and Anderson, 1991). However, Langer and Gehring (1993) proposed that certain 


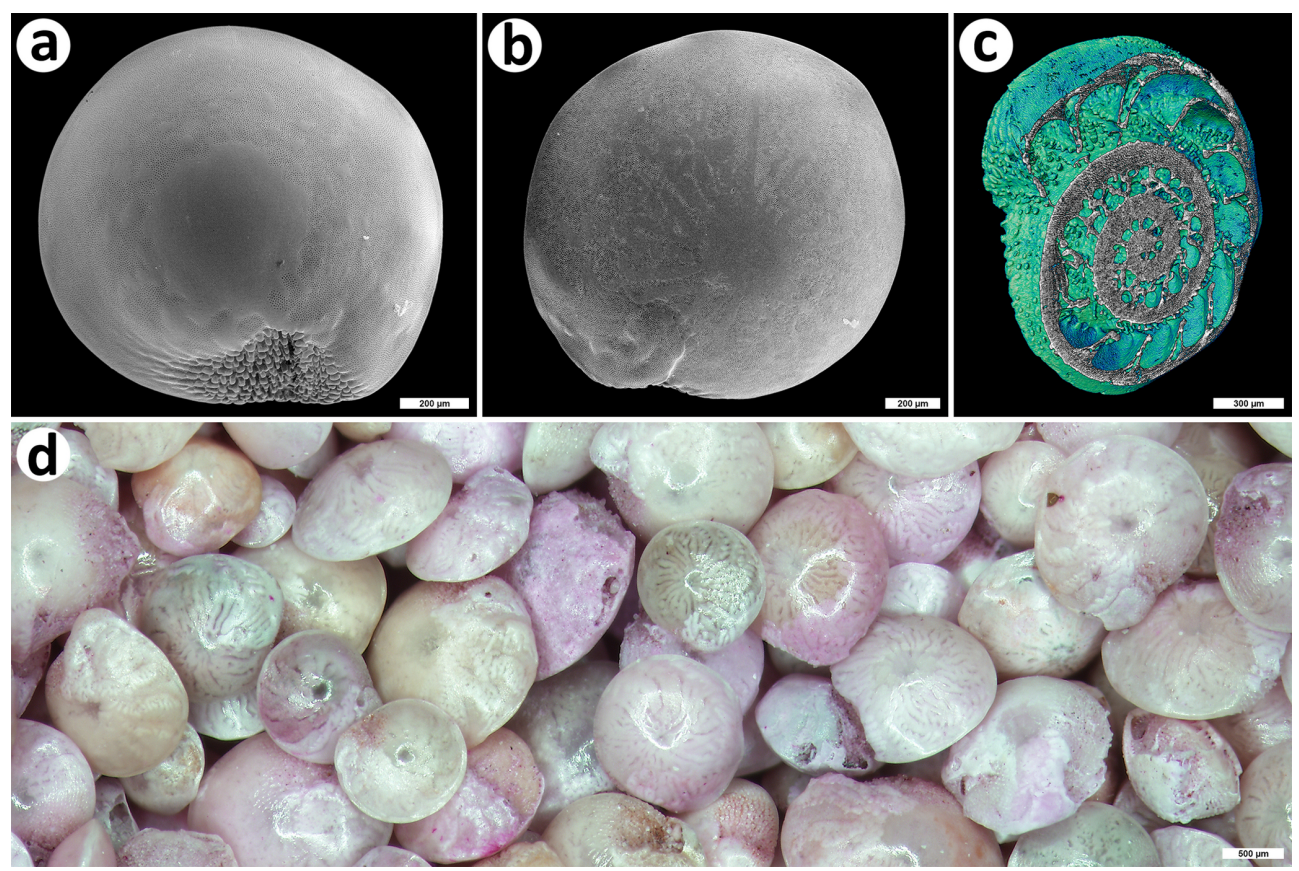

Figure 1. The invasive foraminiferan Amphistegina lobifera from Balluta Bay, St. Julian's, Malta. (a) Ventral view, SEM; bar is $200 \mu$ m; (b) dorsal view, SEM; bar is $200 \mu \mathrm{m}$; (c) micro-CT 3D reconstruction (colored to contrast inner structure); bar is $300 \mu \mathrm{m}$; (d) magnified view of an A. lobifera assemblage (some specimens stained with rose bengal); bar is $500 \mu \mathrm{m}$. The shells were collected by Martin Vohník; photos were taken by Jiří Machač, Institute of Botany, Czech Academy of Sciences, Průhonice, under Martin Vohník’s supervision (a, b) and Zuzana Heřmanová, National Museum, Prague, (c) and Martin Vohník (d).

small motile epiphytic species that produce organic traces consisting of sulfated glycosaminoglycans might do so to farm bacteria and fungi for subsequent consumption. In addition, in the intracellular content of some intertidal benthic forams investigated by Chronopoulou et al. (2019), there was a high relative abundance of fungal DNA (belonging to the members of Saccharomycetes and Exobasidiomycetes), suggesting some kind of a potential trophic interaction. While it is difficult to imagine that forams could extracellularly digest or graze intact living mycelium, they might feed on the often very minute fungal spores and/or bacteria living in the hyphosphere, as proposed for some soil testate amoebae (Vohník et al., 2009, 2011).

Fungi are not only saprobic decomposers but also engage in various symbiotic interactions along the mutualisticparasitic continuum. In the Mediterranean context, a rather curious fungal symbiosis is that with the roots of the dominant seagrass Posidonia oceanica (Alismatales: Posidoniaceae). While the first detailed observations upon the root anatomy of the seagrass had been published ca. 130 years ago (Sauvageau, 1889), the symbiosis was discovered only recently (Vohník et al., 2015). However, since the discovery, it has been reported from every single investigated site in the NW Mediterranean Sea (Borovec and Vohník, 2018; Vohník et al., 2016, 2017). It is formed by a single ascomycetous mycobiont not known from any other host or environment that was very recently described as Posidoniomyces atricolor (Pleosporales: Aigialaceae) (Vohník et al., 2019). Despite its apparent omnipresence in the whole northern Mediterranean Sea (personal observation) and the fact that it morphologically resembles the dark septate endophytic association ubiquitous in the roots of the majority of the terrestrial plants (e.g., Lukešová et al., 2015), next to nothing is known about its functioning as well as significance for both the mycobiont and the host seagrass. Nevertheless, besides the dominant $P$. atricolor, some other fungi associate with $P$. oceanica roots, including Corollospora maritima (Microascales: Halosphaeriaceae) (Cuomo et al., 1985), an ascomycete found to form sporocarps on the shells of Amphistegina sp. from Hawaii (see Fig. 1 in Kohlmeyer, 1985).

In January 2017, during a search for the phytomyxid colonizing another Lessepsian migrant from the Red Sea, i.e., the seagrass Halophila stipulacea (Alismatales: Hydrocharitaceae; see Kolátková et al., 2021), I encountered an abundant A. lobifera population at Balluta Bay, St. Julian's, Malta. At some places, its numerous shells formed layers many centimeters thick, evoking a Mediterranean version of the tropical living sands (Fig. 2a). While I had not found any H. stipulacea, the site was occupied by vigorous patches of $P$. oceanica whose leaves often protruded from the seabed substrate full of A. lobifera shells (Fig. 2b). 

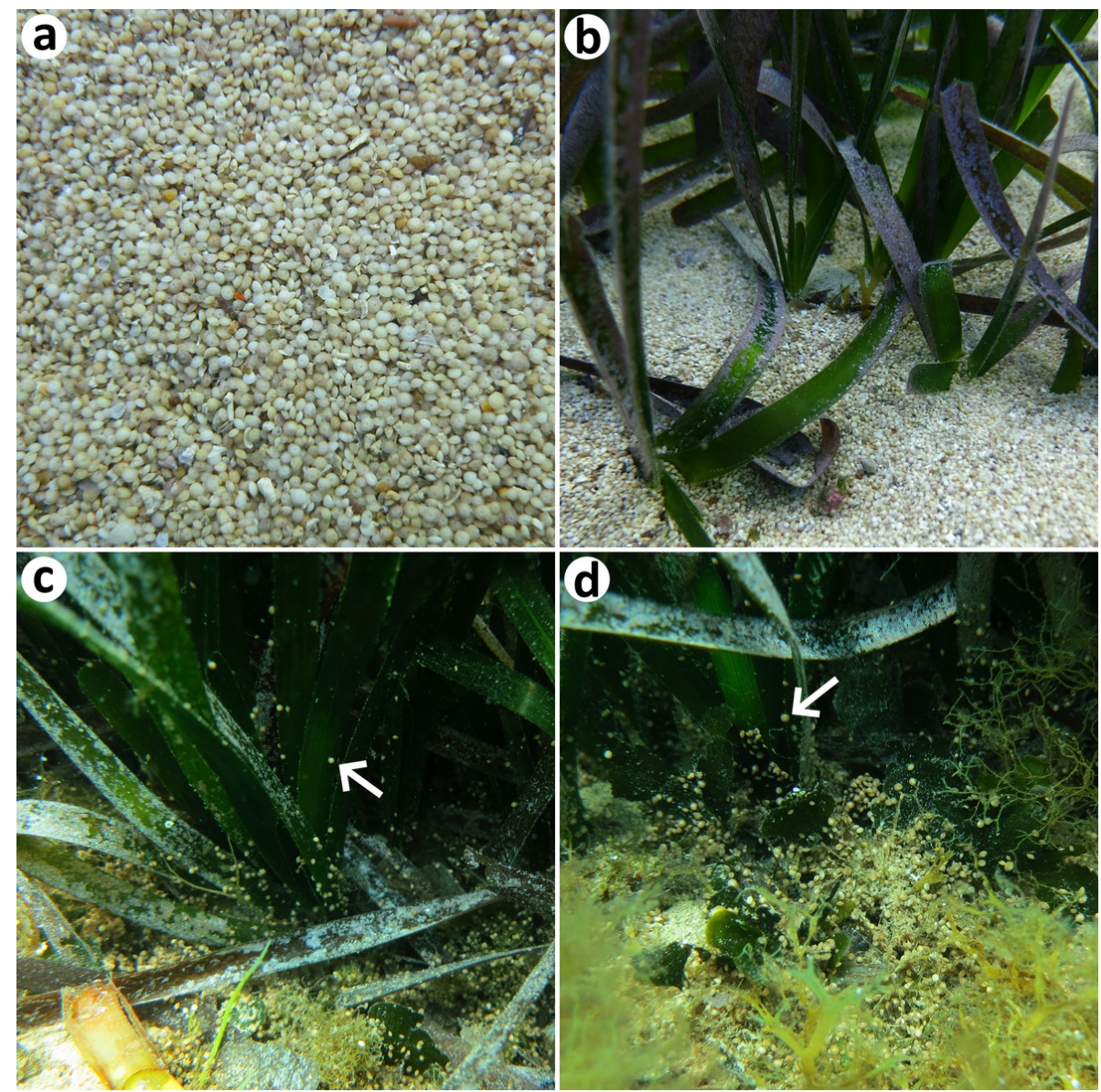

Figure 2. Substrate and epiphytic communities of the invasive foraminiferan Amphistegina lobifera investigated in this study. (a) In situ view of the investigated seabed substrate containing numerous A. lobifera specimens; (b) leaves of the seagrass Posidonia oceanica being buried in the substrate containing numerous A. lobifera specimens; (c, d) epiphytic specimens of $A$. lobifera occurring on the leaves of $P$. oceanica (arrows) and the surrounding seaweeds. All photos taken by Martin Vohník.

At places of their high abundance, Butcher and Steinker (1979) encouraged studies of factors contributing to foram bioerosion, because an understanding of the mechanisms of diagenesis of their shells would significantly contribute to interpretation of the history of carbonate depositional environments. In addition, Kohlmeyer (1985) suggested that representatives of the genus Amphistegina might be good sources of recent "higher" marine fungi (that colonize and bioerode their shells). Hence, I returned to the same place in May 2018, collected samples of A. lobifera shells from the rhizosphere of the seagrass (and epiphytic specimens + the seagrass roots for comparison) and investigated them using various approaches (vital staining, stereomicroscopy, light and scanning electron microscopy (SEM), and fungal isolation and DNA fingerprinting): first to assess the vital status of the A. lobifera specimens as well as their frequency in the substrate and second to address two central questions of this study; i.e., (1) what is the fate of dead A. lobifera shells in the $P$. oceanica rhizosphere and (2) do the fungi inhabiting the seagrass roots colonize the dead shells and thus contribute to their bioerosion? Since the seagrass roots are tightly coupled with a unique spectrum of marine fungi (see above), I hypothesized that these would be the primary bioeroders of dead A. lobifera shells.

\section{Materials and methods}

\subsection{Sampling}

Epiphytic specimens of Amphistegina lobifera, rhizosphere substrate and roots of the seagrass Posidonia oceanica were collected using scuba diving at three different microsites (ca. $10 \mathrm{~m}$ apart) at a depth of ca. $6 \mathrm{~m}$ at Balluta Bay, St. Julian's, Malta (GPS: $35.915685^{\circ} \mathrm{N}, 14.495578^{\circ} \mathrm{E}$ ) on 28 May 2018. The epiphytic specimens originated from $P$. oceanica leaves and seaweeds growing in the immediate vicinity of the seagrass (mostly Dictyota dichotoma) (Fig. 2c, d). The former was in situ scraped off the surface of the leaves using opened 
$50 \mathrm{~mL}$ plastic test tubes, the latter was individually collected with tweezers from the seaweed surface in the laboratory and both were eventually pooled (no attempt was made to calculate an exact seagrass-to-seaweed ratio, but the majority of the epiphytic shells were from seaweeds). To obtain the rhizosphere substrate, $P$. oceanica rhizomes with intact healthy-looking leaves were gently lifted up a little, and the substrate right below was collected into opened $50 \mathrm{~mL}$ plastic test tubes with seawater. All samples were divided in two subsamples of equal volume: one for (stereo)microscopic screening and one for mycobiont isolation, and they were processed as described below.

\subsection{Screening of Amphistegina shells and Posidonia roots}

The subsamples containing A. lobifera shells were further divided into halves; one-half was stained for 2 weeks with rose bengal (stains proteins in the protoplasm), washed repeatedly with tap water and dried to distinguish alive and dead specimens (Walton, 1952), while the other half was dried and used for counting (to establish the abundance of A. lobifera specimens in $1 \mathrm{~g}$ of the dried substrate), weighing (the total weight of A. lobifera specimens in $1 \mathrm{~g}$ of the dried substrate), measuring (the diameter of the substrate specimens) and (stereo)microscopy (to document bioerosion/colonization, dissolution and mechanical damage of the epiphytic + substrate specimens). To measure the diameter of the substrate specimens, $100 \mathrm{mg}$ of random substrate shells per each microsite were separated, and the measurements were performed on all shells occurring in three separate fields of view using an Olympus SZX12 stereomicroscope (magnification $12.5 \times$ ) and the QuickPHOTO MICRO ver. 3.2 software (Promicra, Czechia).

To document bioerosion/colonization, the respective shells were first roughly screened using the stereomicroscope, and subsequently, 30 random shells per type and microsite were assessed using a FEI Quanta 200 ESEM scanning electron microscope (FEI Company, USA) in the "Low Vacuum" mode at room temperature (detailed SEM screening is a lengthy process so the total number of screened shells was primarily limited by the working time available at the SEM microscope). With respect to bioerosion/dissolution, they were sorted out into six qualitative categories, i.e., (1) intact (meaning not affected, Fig. 1), (2) non-bioeroded but partially dissolved, (3) bioeroded and partially dissolved, (4) only bioeroded - low level, (5) only bioeroded - intermediate level, and (6) only bioeroded - high level (of bioerosion). Additionally, surface colonization by macroepiphytes and mechanical damage were recorded (independently of the former six categories) (for illustration see Fig. 3). I did not attempt to determine the respective microborers taxonomically; instead, they were conservatively distinguished into two classes, i.e., fungi and non-fungal organisms. Because the traditional sorting based on the diameter of the bores (e.g., Perkins and Halsey, 1971) is not very reliable (see Golubić et al., 1975), the bores were assigned to the former class only when intact hyphae were first observed on the shell surface using a stereomicroscope (for illustration, see Fig. 4).

Random $P$. oceanica root segments from each microsite were screened for fungal colonization using a compound Olympus BX60 microscope at high magnifications (400× and $1000 \times$ ) as detailed in Vohník et al. (2015). In brief, the fine terminal roots were separated from the root system, washed with tap water, and their transversal and longitudinal semi-thin sections were prepared using a razor blade, and these were mounted in lactoglycerol on glass slides and evaluated for fungal colonization using the compound microscope.

Stereomicroscopy and light microscopy photographs were taken with an Olympus DP70 camera; the "Deep Focus Mode" embedded in QuickPHOTO MICRO ver. 3.2 was employed when needed. The obtained photos were modified for clarity and contrast as needed and assembled into figures using Paint.net ver. 4.0.13 (dotPDN LLC, Rick Brewster and contributors).

\subsection{Mycobiont isolation and identification}

The protocol for isolation and identification of fungi colonizing A. lobifera shells and P. oceanica terminal roots comprised methods identical to those described in more detail in Vohník (2020); this paper also describes their rationale and intuitive troubleshooting. In brief, the low-carbon Potato Carrot Agar (PCA) used for mycobiont isolation was prepared by boiling $40 \mathrm{~g}$ of carrots and $40 \mathrm{~g}$ of potatoes separately in $500 \mathrm{~mL}$ of deionized water for $5 \mathrm{~min}$. The resulting broth was autoclaved at $121^{\circ} \mathrm{C}$ for $20 \mathrm{~min}$, diluted $1: 1$ with sterile deionized water, supplemented with agar $\left(10 \mathrm{~g} \mathrm{~L}^{-1}\right.$; HiMedia, India), again autoclaved at $121^{\circ} \mathrm{C}$ for $20 \mathrm{~min}$, and, when cooled but still liquid, supplemented with Novobiocin sodium salt (50 $\mathrm{m} \mathrm{L}^{-1}$; Sigma-Aldrich, Germany) to prevent growth of bacteria. The medium was poured into plastic, square 25-compartment Petri dishes and left to solidify under UV light overnight.

Fifty epiphytic and 50 substrate shells and 50 root segments (ca. 3-4 mm long) were selected randomly from the samples from all three microsites. The shells and the root segments were surface-sterilized for $30 \mathrm{~s}$ in $10 \%$ SAVO (common household bleach; Unilever, Czechia; $100 \%$ SAVO contains $47 \mathrm{~g} \mathrm{~kg}^{-1}$, i.e., $4.7 \%$, sodium hypochlorite, $\mathrm{NaClO}$ ), $3 \times$ washed with sterile deionized water and then transferred onto the surface of the solidified medium in the dishes. Additionally, 25 substrate shells from one microsite were not surface-sterilized but only serially washed with sterile deionized water and then treated as above, serving as a control treatment. The isolations took place during the day of collection. Petri dishes with the shells and root segments were incubated at room temperature in the dark and periodically checked for fungal growth. After 6 months, all visi- 

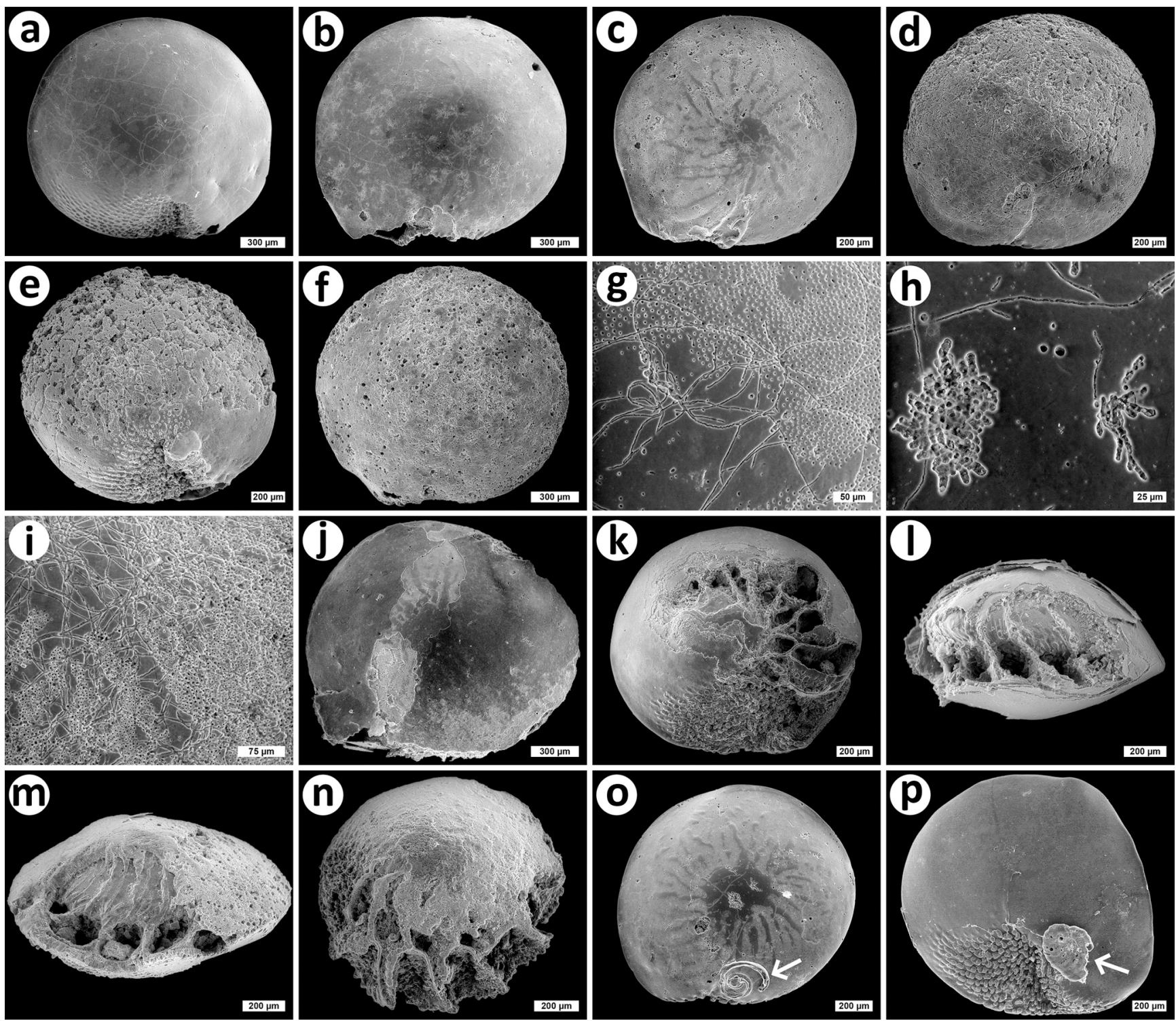

Figure 3. Examples of bioerosion, abiotic dissolution and epiphytic colonization of shells of the invasive foraminiferan Amphistegina lobifera visualized by scanning electron microscopy. Amphistegina lobifera substrate shells displaying low (a), medium (b, c) and high (d, e, f) levels of bioerosion (cf. Table 1); (g, h, i) typical bioerosion traces found in the substrate shells; (j-n) various degrees of abiotic dissolution, sometimes combined with bioerosion $(\mathbf{j}, \mathbf{m}, \mathbf{n}) ;(\mathbf{o}, \mathbf{p})$ examples of epiphytes on A. lobifera shells (arrows). Bars are $300 \mu \mathrm{m}(\mathbf{a}, \mathbf{b}, \mathbf{f}, \mathbf{j})$, $200 \mu \mathrm{m}$ (c, d, e, k-p), $75 \mu \mathrm{m}$ (i), $50 \mu \mathrm{m}$ (g) and $25 \mu \mathrm{m}$ (h). The shells were collected by Martin Vohník, and all photos were taken by Jiří Machač under Martin Vohník’s supervision.

ble fungal cultures were counted, assigned codes and identified as detailed below. As Posidoniomyces atricolor, the dominant root mycobiont of Posidonia oceanica, is notoriously slow-growing (Vohník et al., 2019), the dishes were reexamined after another 5 months, and all new cultures were counted, assigned codes and identified as detailed below.

For mycobiont molecular identification, total DNA was extracted from all fungal cultures producing enough mycelium using an Extract-N-Amp Plant Kit (SigmaAldrich, Germany) following manufacturer's instructions.
The ITS1-5.8S-ITS2 region (ITS, meaning internal transcribed spacer) of the nuclear ribosomal DNA (nrDNA) was amplified using the ITS1F + ITS4 primer pair, and the partial large subunit (LSU) nrDNA of some isolates was amplified using the LR0R + LR7 primer pair. The PCR and gel electrophoresis parameters were the same as in Vohník et al. (2016). The PCR products were purified and sequenced in the Macrogen Europe Laboratory (Macrogen Europe, the Netherlands) using the ITS1, ITS4, LR0R and LR7 primers. 

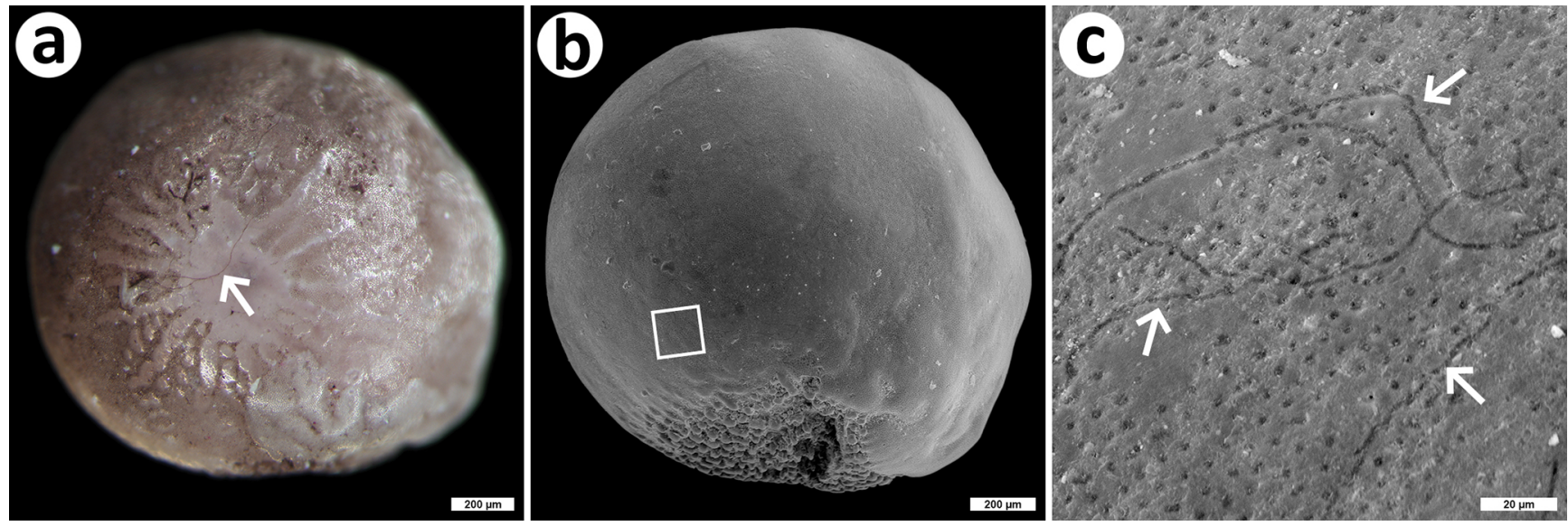

Figure 4. An example of fungal colonization of a shell of the invasive foraminiferan Amphistegina lobifera. (a) Dorsal view of an A. lobifera shell apparently colonized by dark brown mycelium (arrow), stereomicroscopy; bar is $200 \mu \mathrm{m}$; (b) ventral view of the same shell as in (a), SEM; bar is $200 \mu \mathrm{m}$; the square delimits the area magnified in (c) and displaying fungal traces on the surface (arrows), SEM; bar is $20 \mu \mathrm{m}$. The shell was collected by Martin Vohník, and photos were taken by Martin Vohník (a) and Jiří Machač under Martin Vohník’s supervision (b, c).

The obtained sequences were screened in Finch TV v1.4.0 (https://digitalworldbiology.com/FinchTV, last access: November 2020) for possible machine errors and manually edited and trimmed. Where available, the reverse sequences (i.e., those obtained with the ITS4 and LR7 primers) were converted to reverse complement sequences and aligned with the corresponding forward sequences, yielding consensus sequences (contigs) representing the respective fungal isolates. The resulting ITS sequences were subsequently subjected to BLAST searches in GenBank, and those not belonging to Posidoniomyces atricolor were aligned in ClustalW (Thompson et al., 1994) implemented in BioEdit v7.2.5 (Hall, 1999). The resulting alignment was used as a matrix for a neighbor-joining (NJ) analysis (default settings) in TOPALi v2.5 (Biomathematics and Statistics Scotland, http://www.topali.org/, last access: November 2020) to delimit molecular operational taxonomic units (MOTUs); the threshold limit for grouping of sequences was set at $99 \%$. One MOTU (no. 14) was delimited based on the only available LSU sequences. Sequences within separate MOTUs were further aligned to screen their heterogeneity, and their taxonomic position was checked using Blast Tree View (NJ, default settings). Fungal taxonomy follows the MycoBank database (https://www.mycobank.org/, last access: October 2020).

\section{Results}

\subsection{Screening of Amphistegina shells and Posidonia roots}

On average, $78.1 \%$ of the epiphytic A. lobifera specimens were alive (averages for the three microsites: $53.7 \%, 83.3 \%$ and $97.4 \%$ ). In contrast, a great majority (>99\%) of the substrate specimens from all three microsites were dead. On average, there were 284 specimens in $1 \mathrm{~g}$ of the dried substrate $(395,282$ and 175 shells), representing on average $28.5 \%$ of the total weight of the dried substrate $(43.1 \%$, $26.5 \%$ and $15.8 \%$ ). The average diameter of the substrate shells was $1.32 \pm 0.23 \mathrm{~mm}$ (mean $+\mathrm{SD}$; $\min 0.52$, $\max$ $2.08 \mathrm{~mm}$ ).

On average, $80 \%$ of the epiphytic A. lobifera shells were intact (i.e., showed no signs of biotic or abiotic degradation) compared to only $21 \%$ of the substrate shells. Only abiotic dissolution was observed in just a few shells $(2 \%$ and $8 \%$, respectively). Whereas some degree of bioerosion was observed on average only in $18 \%$ of the epiphytic shells, it was $>70 \%$ in the case of the substrate shells. Highly bioeroded shells were on average $3 \%$ of the epiphytic shells compared to $13 \%$ of the substrate shells (for details see Table 1, for examples see Fig. 3). Only a minor part of the bioerosion traces could be unambiguously attributed to fungi, typically only in a combination of stereomicroscopy followed by SEM (Fig. 4).

All screened root segments displayed the dark septate endophytic colonization typical for $P$. oceanica collected in the NW Mediterranean Sea (Fig. 5a) that has been documented in terms of morphology, anatomy and ultrastructure in several recent papers (see above).

\subsection{Mycobiont isolation and identification}

In total, 107 fungal isolates were obtained from the 150 surface-sterilized $P$. oceanica root segments (86 isolates; ca. $57 \%$ isolation success) and the 150 epiphytic (19; ca. $13 \%)$ and the 25 non-sterilized substrate (2; ca. $8 \%$ ) shells of A. lobifera. The 150 surface-sterilized A. lobifera shells yielded no isolate. Out of these, 97 were identified with the aid of molecular fingerprinting (Table 2), and they belonged 
Table 1. Bioerosion, abiotic dissolution, macroepiphytic colonization and mechanical damage of Amphistegina lobifera shells in numbers. Epiphytic and substrate shells of the invasive foraminiferan A. lobifera were collected at three different microsites at a depth of ca. $6 \mathrm{~m}$ at Balluta Bay, St. Julian's, Malta; for details on their investigation see Sect. 2.

\begin{tabular}{|c|c|c|c|c|c|c|c|c|c|}
\hline \multirow{2}{*}{$\begin{array}{l}\text { Microsite } \\
\text { no. }\end{array}$} & \multirow{2}{*}{$\begin{array}{l}\text { Type of } \\
\text { shells } \\
(n=30)\end{array}$} & \multicolumn{6}{|c|}{ Categories of shell bioerosion or abiotic dissolution } & \multirow{2}{*}{$\begin{array}{r}\text { No. of } \\
\text { shells with } \\
\text { macroepiphytes }\end{array}$} & \multirow{2}{*}{$\begin{array}{r}\text { No. of } \\
\text { mechanically } \\
\text { damaged } \\
\text { shells }\end{array}$} \\
\hline & & $\begin{array}{r}1: \text { intact } \\
(\text { not } \\
\text { affected) }\end{array}$ & $\begin{array}{r}2 \text { : only } \\
\text { partially } \\
\text { dissolved }\end{array}$ & $\begin{array}{r}\text { 3: bioeroded } \\
+ \text { partially } \\
\text { dissolved }\end{array}$ & $\begin{array}{r}\text { 4: only } \\
\text { bioeroded } \\
- \text { low }\end{array}$ & $\begin{array}{r}5: \text { only } \\
\text { bioeroded } \\
- \text { medium }\end{array}$ & $\begin{array}{r}\text { 6: only } \\
\text { bioeroded } \\
- \text { high }\end{array}$ & & \\
\hline \multirow{2}{*}{1} & Epiphytic & 20 & 0 & 1 & 4 & 3 & 2 & 1 & 2 \\
\hline & Substrate & 8 & 3 & 5 & 8 & 2 & 4 & 1 & 5 \\
\hline \multirow{2}{*}{2} & Epiphytic & 27 & 1 & 1 & 0 & 0 & 1 & 1 & 0 \\
\hline & Substrate & 5 & 2 & 4 & 6 & 6 & 7 & 2 & 3 \\
\hline \multirow{2}{*}{3} & Epiphytic & 25 & 1 & 0 & 2 & 2 & 0 & 1 & 0 \\
\hline & Substrate & 6 & 2 & 5 & 14 & 2 & 1 & 2 & 0 \\
\hline \multirow{2}{*}{$\begin{array}{l}\text { Average } \\
\text { (all sites) }\end{array}$} & Epiphytic & $80 \%$ & $2 \%$ & $2 \%$ & $7 \%$ & $6 \%$ & $3 \%$ & $4 \%$ & $2 \%$ \\
\hline & Substrate & $21 \%$ & $8 \%$ & $16 \%$ & $31 \%$ & $11 \%$ & $13 \%$ & $3 \%$ & $9 \%$ \\
\hline
\end{tabular}

to 14 distinct MOTUs (Table 3). While the epiphytic shells yielded 12 MOTUs that were mostly represented by a single isolate ( $\max t w o$ ), the root segments yielded two other MOTUs represented by 67 and 14 morphologically distinct isolates (Fig. 5b). There were no overlaps between the shelland root-associated MOTUs (Table 3).

The epiphytic shell mycobiota comprised generalists like Alternatia, Cladosporium and Penicillium spp., known also from terrestrial ecosystems, alongside one isolate probably representing a new species in the genus Knufia and four MOTUs that could be reliably identified only at the class level. The root mycobiota was at all three microsites dominated by $P$. atricolor whose compact blackish slow-growing colonies (Fig. 5b, c) appeared to develop from intraradical (micro)sclerotia (Fig. 5d). However, at one microsite, the root segments also yielded a previously unreported lulworthioid mycobiont (MOTU 14) probably representing a new species in the Lulworthiales order (Table 3).

\section{Discussion}

This study took place close to the current NW distribution limit of the alien foram Amphistegina lobifera in the western basin of the Mediterranean Sea, yet the abundance of its shells in the seabed substrate was comparable with or even exceeded those reported from the comparably warmer eastern basin (average $28.5 \%$ reported here vs. $32.7 \%$ reported from the Antalya coast in Turkey; see Yokeş et al., 2014; $\max 395$ shells g ${ }^{-1}$ reported here vs. max 178 shells g ${ }^{-1}$ reported from the Israeli coast; see Hyams et al., 2002). Thus, despite the fact that the thickness of the substrate containing A. lobifera shells by far did not reach the impressive 60
$80 \mathrm{~cm}$ reported by Yokeş and Meriç (2009), the alien foram shells did represent a significant part of the bottom sediment at the investigated Maltese locality and profoundly changed the seabed character (i.e., from calcareous rocks combined with mineral sand and pebbles to a homogenous layer with a large proportion formed by the biogenic calcareous matter; see Fig. 2a, b and also see Langer et al., 2012). Interestingly, in contrast to the tropical living sands, practically all $A$. lobifera substrate specimens were dead. On the other hand, a similar finding has been reported, for example, for substrate shells from Key Largo, Florida, USA (Martin and Wright, 1988). The seagrass Posidonia oceanica is known to produce "matte", i.e., an important seabed sediment composed of siliciclastic and biogenic carbonated materials mixed in various ratios with organic matter (mainly P. oceanica roots, rhizomes and leaves) that can be several meters thick and thousands of years old (e.g., Serrano et al., 2012). From the biogeological point of view, it would be interesting to investigate how the matte formation is influenced by the accumulation of dead A. lobifera shells in the seabed substrate.

Investigations of the processes beyond the foram shell breakdown and turnover are important not only because of the information loss and taphonomic bias inherent to the transition from living to dead foram assemblages (e.g., Martin and Wright, 1988) but also for a better understanding of the factors limiting the accumulation of alien foram shells in the invaded ecosystems, such as through abiotic dissolution (e.g., Green et al., 1993) and bioerosion (e.g., Cherchi et al., 2012), transformation of the shells into lime mud, i.e., the important matrix of both recent and ancient calcareous sediments (e.g., Debenay et al., 1999), etc. Here, while the abiotic dissolution and mechanical damage contributed only little, the majority $(>70 \%)$ of the substrate shells showed at least some signs 

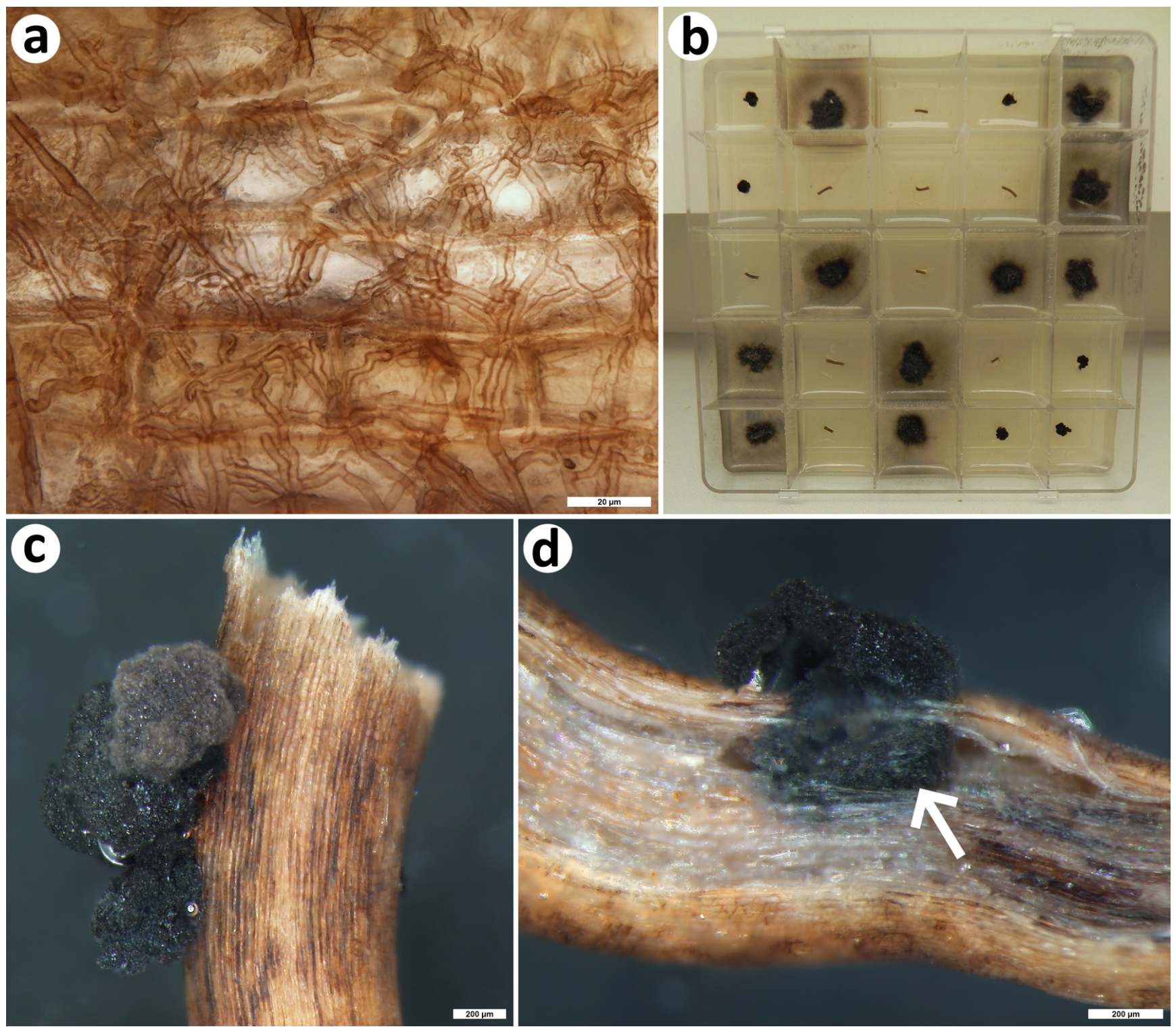

Figure 5. Colonization pattern and root mycobionts of the dominant Mediterranean seagrass Posidonia oceanica. (a) The typical colonization pattern in the seagrass roots that resembles the ubiquitous terrestrial dark septate endophytes, light microscopy; (b) 25-compartment plastic Petri dish filled with nutrient medium and with fungal colonies emerging from some of the surface-sterilized seagrass root segments. Note that one morphotype produces diffuse substrate mycelium (it corresponds to MOTU no. 14, i.e., the Lulworthiales sp. MV-2018; see Table 3), while the other remains small and limited to the surface of the root segments or their immediate vicinity (MOTU no. 13, i.e., Posidoniomyces atricolor). In this particular case, nine root segments did not yield any fungal mycelium; that is, the isolation success reached $64 \%$. (c) Detail of compact colonies of $P$. atricolor emerging from a surface-sterilized root segment, stereomicroscopy; bar is $200 \mu \mathrm{m}$; (d) longitudinal section through a root segment yielding a compact colony of $P$. atricolor; note that the surface mycelium originates from an enlarged intraradical sclerotium (arrow), stereomicroscopy; bar is $200 \mu \mathrm{m}$. All photos taken by Martin Vohník.

of bioerosion, with $13 \%$ being highly bioeroded. This is opposite to, e.g., the findings of Berkeley et al. (2009), who investigated tropical intertidal sediments in north Queensland, Australia, and concluded that the calcareous test degradation during early burial was primarily driven by dissolution not bioerosion. However, the reason(s) for this difference remains unknown. Nevertheless, the data gathered here suggest that bioerosion may, at least to a certain degree, counterbalance the accumulation of alien foram shells in the seabed and thus alleviate the negative impact of the alien foram environmental engineering (cf. Yokeş and Meriç, 2009; Zenetos et al., 2008, and also see Langer et al., 2012).

Surprisingly, a great majority of the bioerosion traces seemed to belong to non-fungal organisms (probably 
Table 2. Results of mycobiont isolation from shells of the foraminiferan Amphistegina lobifera and roots of the seagrass Posidonia oceanica. The mycobionts were isolated into pure cultures and the molecular operational taxonomic units (MOTUs) were delimited as described in Sect. 2.

\begin{tabular}{|c|c|c|c|c|c|c|}
\hline \multirow{2}{*}{$\begin{array}{l}\text { Sample type } \\
\text { Amphistegina lobifera } \\
\text { epiphytic shells }\end{array}$} & \multicolumn{2}{|c|}{ Microsite no. 1} & \multicolumn{2}{|c|}{ Microsite no. 2} & \multicolumn{2}{|c|}{ Microsite no. 3} \\
\hline & $\begin{array}{l}8 \text { isolates } \\
(6 \text { identified })\end{array}$ & $\begin{array}{l}6 \text { MOTUs } \\
(\text { nos. } 1,5,6,8,9,11)\end{array}$ & $\begin{array}{l}4 \text { isolates } \\
\text { (all identified) }\end{array}$ & $\begin{array}{l}3 \text { MOTUs } \\
(\text { nos. } 1,7,12)\end{array}$ & $\begin{array}{l}7 \text { isolates } \\
\text { (6 identified) }\end{array}$ & $\begin{array}{l}4 \text { MOTUs } \\
(\text { nos. } 2,3,4,10)\end{array}$ \\
\hline $\begin{array}{l}\text { Amphistegina lobifera } \\
\text { substrate shells* }\end{array}$ & 0 isolates & - & $\begin{array}{l}2 \text { isolates } \\
(0 \text { identified })\end{array}$ & - & 0 isolates & - \\
\hline $\begin{array}{l}\text { Posidonia oceanica } \\
\text { root segments }\end{array}$ & $\begin{array}{l}19 \text { isolates } \\
\text { (17 identified) }\end{array}$ & $\begin{array}{l}1 \mathrm{MOTU} \\
\text { (no. 13) }\end{array}$ & $\begin{array}{l}29 \text { isolates } \\
\text { (all identified) }\end{array}$ & $\begin{array}{l}1 \mathrm{MOTU} \\
\text { (no. 13) }\end{array}$ & $\begin{array}{l}38 \text { isolates } \\
\text { (35 identified) }\end{array}$ & $\begin{array}{l}2 \text { MOTUs } \\
\text { (nos. } 13,14)\end{array}$ \\
\hline
\end{tabular}

* Data only for non-sterilized substrate shells (surface-sterilized substrate shells yielded no isolate).

Table 3. Taxonomic affinities of the molecular operational taxonomic units representing mycobionts isolated in this study. Taxonomic affinities (identity) of the delimited molecular operational taxonomic units (MOTUs) are based on comparing representative ITS and/or LSU nrDNA sequences with those available in a public database (i.e., GenBank at NCBI) as described in Sect. 2.

\begin{tabular}{|c|c|c|c|}
\hline $\begin{array}{l}\text { MOTU } \\
\text { no. }\end{array}$ & $\begin{array}{l}\text { MOTU occurrence (no. of } \\
\text { identified isolates)* }\end{array}$ & MOTU identity & Reference isolates [their sequences in GenBank] \\
\hline 1 & EPI-1 (1), EPI-2 (2) & Penicillium sp. MV-2018A & MLT-5 [MT636974 (ITS)] \\
\hline 2 & EPI-3 (2) & Penicillium sp. MV-2018B & MLT-56 [MT636983 (ITS)] \\
\hline 3 & EPI-3 (1) & Penicillium sp. MV-2018C & MLT-55 [MT636982 (ITS)] \\
\hline 4 & EPI-3 (2) & Penicillium sp. MV-2018D & MLT-51 [MT636980 (ITS)] \\
\hline 5 & EPI-1 (1) & Knufia sp. MV-2018 & MLT-8 [MT636977 (ITS), MT636937 (LSU)] \\
\hline 6 & EPI-1 (1) & Dothideomycetes sp. MV-2018A & MLT-7 [MT636976 (ITS)] \\
\hline 7 & EPI-2 (1) & Alternaria sp. MV-2018 & MLT-28 [MT636979 (ITS), MT636939 (LSU)] \\
\hline 8 & EPI-1 (1) & Dothideomycetes sp. MV-2018B & MLT-4 [MT636973 (ITS), MT636936 (LSU)] \\
\hline 9 & EPI-1 (1) & Sordariomycetes sp. MV-2018A & MLT-6 [MT636975 (ITS)] \\
\hline 10 & EPI-3 (1) & Sordariomycetes sp. MV-2018B & MLT-52 [MT636981 (ITS), MT636940 (LSU)] \\
\hline 11 & EPI-1 (1) & Cladosporium sp. MV-2018A & MLT-3 [MT636972 (ITS), MT636935 (LSU)] \\
\hline 12 & 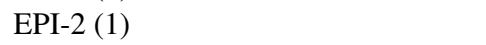 & Cladosporium sp. MV-2018B & MLT-27 [MT636978 (ITS), MT636938 (LSU)] \\
\hline 13 & POS-1 (17), POS-2 (29), POS-3 (21) & Posidoniomyces atricolor & MLT-87 [MT636984 (ITS)] \\
\hline 14 & POS-3 (14) & Lulworthiales sp. MV-2018 & MLT-72 [MT636941 (LSU)] \\
\hline
\end{tabular}

* EPI represents epiphytic shells of the foraminiferan Amphistegina lobifera, POS represents terminal roots of the seagrass Posidonia oceanica. The numbers after the codes (i.e., 1, 2 and 3) represent the three sampling microsites (see Table 1).

cyanobacteria and/or microscopic algae). Congruently, and in contrast to the main hypotheses, not only did the substrate shells not share any fungi with the P. oceanica roots but they also did not yield any cultivable fungi at all. This is an unexpected result, because cultivable fungi are ubiquitous in marine ecosystems and regularly colonize calcareous substrates including foram shells (cf. Kohlmeyer, 1969, 1984, 1985). In addition, the epiphytic shells were colonized by fungal ubiquitous generalists as well as specialists, and the seagrass roots were regularly colonized by specific symbiotic fungi, including a member of the Lulworthiales that comprise common marine ascomycetes, with some of them colonizing foram shells (see Kohlmeyer et al., 2000). Nevertheless, a few substrate shells did display apparent signs of fungal colonization by dark septate hyphae (Fig. 4) that actually resembled the mycelium of the dominant $P$. oceanica root mycobiont (see below). However, an attempt to clone fungal DNA from such shells ended with inconclusive results (data not shown).

The disappearance of cultivable fungi from the substrate shells observed in this study is difficult to explain, and one can only speculate about its reasons. For example, since most of the substrate specimens were dead, the respective shells were presumably empty, i.e., without sufficient organic matter to support the fungal growth. However, many marine ascomycetes are notoriously slow-growing (i.e., they need little nutrients), including the dominant $P$. oceanica root mycobiont (see Vohník et al., 2019, and references therein) and, for example, all the foram-associated tropical marine fungi reported by Kohlmeyer $(1984,1985)$ probably developed on and/or within dead shells. A more likely explanation is allelopathy, a phenomenon common also among marine microorganisms (see Hellio et al., 2000; Gross, 2003; Cepas et al., 2019, and many others). Here, the antagonists could 
be the (presumably autotrophic) microbioeroders abundant in the substrate shells and/or the fungi inhabiting $P$. oceanica roots. Indeed, while numerous cultivable fungi have been recently obtained from nearly all $P$. oceanica tissues, they were absent in the apical parts of the leaves that, however, commonly displayed colonization by microscopic algae/cyanobacteria (B. Soperová and M. Vohník, unpublished results). In addition, while it is still unknown, for example, what is the reach of the mycelium of $P$. oceanica rootsymbiotic fungi, it is interesting to note that their diversity is, at least in the NW Mediterranean Sea, extremely low and dominated by a single mycobiont (Vohník et al., 2016, 2017, 2019). While data from other seagrasses are too few to allow for any robust comparisons, such dominance is extremely rare both in freshwater and terrestrial ecosystems (e.g., Vandenkoornhuyse et al., 2002) and might suggest some kind of antagonism between the dominant root mycobiont and other marine fungi.

Also in this study, the seagrass roots were dominated by $P$. atricolor, which is a pleosporalean fungus not known from any other hosts or environments, and the microscopic observations presented here (Fig. $5 \mathrm{c}, \mathrm{d}$ ) provide further indirect evidence that this mycobiont is responsible for the root colonization pattern ubiquitous in the NW Mediterranean Sea (Fig. 5a; see Vohník et al., 2015). The seagrass roots additionally yielded a hitherto unknown lulworthioid mycobiont, and the epiphytic shells yielded an isolate with affinities to the genus Knufia that comprises highly destructive extremotolerant lithobionts that, for example, often bioerode Mediterranean historical monuments exposed to outdoor conditions (see Isola et al., 2016, and references therein). While these isolates represent interesting and potentially important mycobionts and illustrate how little we know about the diversity of marine fungi (cf. Gareth Jones, 2011, and references therein), their more detailed taxonomic assignment remained outside the scope and dimensions of this study.

\section{Conclusions}

In the first study focused on the fate of A. lobifera during early burial in an invaded ecosystem, I found out that practically all its substrate specimens were dead and regularly bioeroded by presumably photoautotrophic microborers not marine fungi. Their taxonomic affinities as well as possible antagonistic interactions with the latter remain unknown and beg further investigations. In contrast, the epiphytic A. lobifera specimens yielded a relatively diverse spectrum of mycobionts, at least in comparison with the roots of the seagrass $P$. oceanica, which comprised both ubiquitous generalist and specialist well-adapted to bioerode calcareous substrates. The switch from fungi in the epiphytic shells to nonfungal organisms in the substrate shells is curious and deserves elucidation, possibly through a study focusing on al- lelopathic interactions between these two microborer guilds. Nevertheless, a few substrate shells were indeed colonized by unidentified fungus/fungi with dark mycelium, and possible future studies on interactions of forams with fungi may consider focusing on foram specimens more intimately associated with seagrass roots.

Data availability. The nrDNA sequences generated in this study (see "Materials and methods" section) were edited and submitted to GenBank at NCBI (GenBank, 2020; https://www.ncbi.nlm.nih.gov/ genbank/, last access: November 2020) by the author. Their accession numbers are MT636935-41 and MT636972-84 (see Table 3).

Competing interests. The author declares that there is no conflict of interest.

Acknowledgements. I wish to thank Viktorie Kolátková for introducing me to the world of forams, the assistance during sampling on Malta and the help with assessing the vital status and abundance of A. lobifera in the samples investigated in this study. I also thank Zuzana Heřmanová for sharing the micro-CT image (Fig. 1c), Jiří Machač for taking the SEM photos and assembling the figures, and Katarína Holcová for leading the Czech Science Foundation project no. 18-05935S "From past to present: fossil vs. recent marine shelled organisms as a substrate for colonization and bioerosion". The advice and comments of Martin R. Langer and Antonino Briguglio (referees) helped to improve an earlier version of this paper and are greatly appreciated. I also thank Hiroshi Kitazato (editor) for the time he kindly invested into the peer review of this paper.

Financial support. This research has been supported by the Czech Science Foundation (grant no. 18-05935S) and the Institute of Botany, Czech Academy of Sciences (grant no. RVO 67985939).

Review statement. This paper was edited by Hiroshi Kitazato and reviewed by Martin R. Langer and Antonino Briguglio.

\section{References}

Amend, A., Burgaud, G., Cunliffe, M., Edgcomb, V. P., Ettinger, C. L., Gutiérrez, M. H., Heitman, J., Hom, E. F. Y., Ianiri, G., Jones, A. C., Kagami, M., Picard, K. T., Quandt, C. A., Raghukumar, S., Riquelme, M., Stajich, J., Vargas-Muñiz, J., Walker, A. K., Yarden, O., and Gladfelter, A. S.: Fungi in the marine environment: Open questions and unsolved problems, MBio, 10, 1-15, https://doi.org/10.1128/mBio.01189-18, 2019.

Berger, W. H.: Foraminiferal ooze: Solution at depths, Science, 156, 383-385, https://doi.org/10.1126/science.156.3773.383, 1967.

Berkeley, A., Perry, C. T., and Smithers, S. G.: Taphonomic signatures and patterns of test degradation on tropical, intertidal benthic foraminifera, Mar. Micropaleontol., 73, 148-163, https://doi.org/10.1016/j.marmicro.2009.08.002, 2009. 
Borovec, O. and Vohník, M.: Ontogenetic transition from specialized root hairs to specific root-fungus symbiosis in the dominant Mediterranean seagrass Posidonia oceanica, Sci. Rep., 8, 1-11, https://doi.org/10.1038/s41598-018-28989-4, 2018.

Briguglio, A. and Hohenegger, J.: How to react to shallow water hydrodynamics: The larger benthic foraminifera solution, Mar. Micropaleontol., 81, 63-76, https://doi.org/10.1016/j.marmicro.2011.07.004, 2011.

Bromley, R. G.: Bioerosion: Eating Rocks for Fun and Profit, Short Courses Paleontol., 5, 121-129, https://doi.org/10.1017/s2475263000002312, 1992.

Butcher, W. A. and Steinker, D. C.: Fungal and bacterial degradation of the test of Archaias angulatus (foraminifera), Micron (1969), 10, 35-36, https://doi.org/10.1016/0047-7206(79)900190, 1979.

Cepas, V., López, Y., Gabasa, Y., Martins, C. B., Ferreira, J. D., Correia, M. J., Santos, L. M. A., Oliveira, F., Ramos, V., Reis, M., Castelo-Branco, R., Morais, J., Vasconcelos, V., Probert, I., Guilloud, E., Mehiri, M., and Soto, S. M.: Inhibition of bacterial and fungal biofilm formation by 675 extracts from microalgae and cyanobacteria, Antibiotics, 8, 1-12, https://doi.org/10.3390/antibiotics8020077, 2019.

Cherchi, A., Buosi, C., Zuddas, P., and De Giudici, G.: Bioerosion by microbial euendoliths in benthic foraminifera from heavy metal-polluted coastal environments of Portovesme (south-western Sardinia, Italy), Biogeosciences, 9, 4607-4620, https://doi.org/10.5194/bg-9-4607-2012, 2012.

Chronopoulou, P.-M., Salonen, I., Bird, C., Reichart, G. J., and Koho, K. A.: Metabarcoding insights into the trophic behavior and identity of intertidal benthic foraminifera, Front. Microbiol., 10, 1-16, https://doi.org/10.3389/fmicb.2019.01169, 2019.

Cuomo, V., Vanzanella, F., Fresi, E., Cinelli, F., and Mazzella, L.: Fungal flora of Posidonia oceanica and its ecological significance, Trans. Br. Mycol. Soc., 84, 35-40, https://doi.org/10.1016/S0007-1536(85)80217-5, 1985.

Debenay, J. P., André, J. P., and Lesourd, M.: Production of lime mud by breakdown of foraminiferal tests, Mar. Geol., 157, 159170, https://doi.org/10.1016/S0025-3227(98)00151-0, 1999.

Denne, R. A. and Sen Gupta, B. K.: Effects of taphonomy and habitat on the record of benthic foraminifera in modern sediments, Palaios, 4, 414-423, https://doi.org/10.2307/3514586, 1989.

El Kateb, A., Stalder, C., Stainbank, S., Fentimen, R., and Spezzaferri, S.: The genus Amphistegina (Benthic foraminifera): Distribution along the southern Tunisian coast, BioInvasions Rec., 7, 391-398, https://doi.org/10.3391/bir.2018.7.4.06, 2018.

Frozza, C. F., Pivel, M. A. G., Suárez-Ibarra, J. Y., Ritter, M. N., and Coimbra, J. C.: Bioerosion on Late Quaternary Planktonic Foraminifera Related to Paleoproductivity in the Western South Atlantic, Paleoceanography and Paleoclimatology, 35, e2020PA003865, https://doi.org/10.1029/2020PA003865, 2020.

Gadd, G. M.: Geomycology, in: Encyclopedia of Geobiology, edited by: Reitner, J. and Thiel, V., Springer, Dordrecht, 416-432, 2011.

Galil, B. S.: The marine caravan-the suez canal and the erythrean invasion, Bridging Divides, Marit. Canals as Invasion Corridors, 83, 207-300, https://doi.org/10.1007/978-1-4020-50473_6, 2006.

Gareth Jones, E. B.: Are there more marine fungi to be described?, Bot. Mar., 54, 343-354, https://doi.org/10.1515/BOT.2011.043, 2011.
GenBank, National Center for Biotechnology Information (NCBI): https://www.ncbi.nlm.nih.gov/genbank/, last access: November 2020.

Golubić, S., Brent, G., and Lecampion, T.: Scanning Electron Microscopy of Endolithic Algae and Fungi Using a Multipurpose Casting-Embedding Technique, Lethaia, 3, 203-209, https://doi.org/10.1111/j.1502-3931.1970.tb01858.x, 1970.

Golubić, S., Perkins, R. D., and Lukas, K. J.: Boring Microorganisms and Microborings in Carbonate Substrates, Study Trace Foss., 229-259, https://doi.org/10.1007/978-3-642-65923-2_12, 1975.

Golubić, S., Friedmann, I., and Schneider, J.: The Lithobiontic Ecological Niche, with Special Reference to Microorganisms, SEPM J. Sediment. Res., 51, 475478, https://doi.org/10.1306/212F7CB6-2B24-11D78648000102C1865D, 1981.

Golubić, S., Radtke, G., and Le Campion-Alsumard, T.: Endolithic fungi in marine ecosystems, Trends Microbiol., 13, 229-235, https://doi.org/10.1016/j.tim.2005.03.007, 2005.

Golubić, S., Schneider, J., Le Campion-Alsumard, T., Campbell, S. E., Hook, J. E., and Radtke, G.: Approaching microbial bioerosion, Facies, 65, 1-17, https://doi.org/10.1007/s10347-0190568-1, 2019.

Green, M. A., Aller, R. C., and Aller, J. Y.: Carbonate dissolution and temporal abundances of Foraminifera in Long Island Sound sediments, Limnol. Oceanogr., 38, 331-345, https://doi.org/10.4319/lo.1993.38.2.0331, 1993.

Gross, E. M.: Allelopathy of Aquatic Autotrophs, CRC. Crit. Rev. Plant Sci., 22, 313-339, https://doi.org/10.1080/713610859, 2003.

Guastella, R., Marchini, A., Caruso, A., Cosentino, C., Evans, J., Weinmann, A. E., Langer, M. R., and Mancin, N.: "Hidden invaders" conquer the Sicily Channel and knock on the door of the Western Mediterranean sea, Estuar. Coast. Shelf Sci., 225, 106234, https://doi.org/10.1016/j.ecss.2019.05.016, 2019.

Hall, T. A.: BioEdit: a user-friendly biological sequence alignment editor and analysis program for Windows 95/98/NT, Nucleic Acids Symp. Ser., 41, 95-98, 1999.

Hellio, C., Bremer, G., Pons, A. M., Le Gal, Y., and Bourgougnon, N.: Inhibition of the development of microorganisms (bacteria and fungi) by extracts of marine algae from Brittany, France, Appl. Microbiol. Biotechnol., 54, 543-549, https://doi.org/10.1007/s002530000413, 2000.

Heřmanová, Z., Bruthansová, J., Holcová, K., Mikuláš, R., Kočová Veselská, M., Kočí, T., Dudák, J., and Vohník, M.: Benefits and limits of x-ray micro-computed tomography for visualization of colonization and bioerosion of shelled organisms, Palaeontol. Electron., 23, a23, https://doi.org/10.26879/1048, 2020.

Hirsch, P., Eckhardt, F. E. W., and Palmer, R. J.: Methods for the study of rock-inhabiting microorganisms-A mini review, J. Microbiol. Methods, 23, 143-167, https://doi.org/10.1016/01677012(95)00017-F, 1995.

Hyams, O., Almogi-Labin, A., and Benjamini, C.: Larger foraminifera of the southeastern Mediterranean shallow continental shelf off Israel, Isr. J. Earth Sci., 51, 169-179, 2002.

Irwin, N. A. T., Tikhonenkov, D. V., Hehenberger, E., Mylnikov, A. P., Burki, F., and Keeling, P. J.: Phylogenomics supports the monophyly of the Cercozoa, Mol. Phylogenet. Evol., 130, 416423, https://doi.org/10.1016/j.ympev.2018.09.004, 2019. 
Isola, D., Zucconi, L., Onofri, S., Caneva, G., de Hoog, G. S., and Selbmann, L.: Extremotolerant rock inhabiting black fungi from Italian monumental sites, Fungal Divers., 76, 75-96, https://doi.org/10.1007/s13225-015-0342-9, 2016.

Kloos, D. P.: Destruction of Tests of the Foraminifer Sorites orbiculus By Endolithic Microorganisms in a Lagoon on Curacao (Netherlands Antilles), Geol. En Mijnb., 61, 201-205, 1982.

Kohlmeyer, J.: The role of marine fungi in the penetration of calcareous substances, Integr. Comp. Biol., 9, 741-746, https://doi.org/10.1093/icb/9.3.741, 1969.

Kohlmeyer, J.: Tropical Marine Fungi, Mar. Ecol., 5, 329-378, https://doi.org/10.1111/j.1439-0485.1984.tb00130.x, 1984.

Kohlmeyer, J.: Marine fungi (Ascomycetes) within and on tests of Foraminifera, Mar. Biol., 90, 147-149, https://doi.org/10.1007/BF00428226, 1985.

Kohlmeyer, J., Spatafora, J. W., and Volkmann-Kohlmeyer, B.: Lulworthiales, a new order of marine Ascomycota, Mycologia, 92, 453-458, https://doi.org/10.2307/3761504, 2000.

Kohlmeyer, J., Volkmann-Kohlmeyer, B., and Newell, S. Y.: Marine and estuarine mycelial Eumycota and Oomycota, in: Biodiversity of Fungi: Inventory and Monitoring Methods, edited by: Mueller, G. M., Foster, M. S., and Bills, G. F., Elsevier Academic Press, Amsterdam, 533-545, 2004.

Kolátková, V., Čepička, I., Hoffman, R., and Vohník, M.: Marinomyxa Gen. Nov. Accommodates Gall-Forming Parasites of the Tropical to Subtropical Seagrass Genus Halophila and Constitutes a Novel Deep-Branching Lineage Within Phytomyxea (Rhizaria: Endomyxa), Microb. Ecol., 81, 673-686, https://doi.org/10.1007/s00248-020-01615-5, 2021.

Kothe, E.: Microbial Degradation, in: Encyclopedia of Geobiology, edited by: Reitner, J. and Thiel, V., Springer, Dordrecht, 596599, 2011.

Kotler, E., Martin, R. E., and Liddell, W. D.: Experimental analysis of abrasion and dissolution resistance of modern reef-dwelling foraminifera: implications for the preservation of biogenic carbonate, Palaios, 7, 244-276, https://doi.org/10.2307/3514972, 1992.

Langer, M. R.: Assessing the contribution of foraminiferan protists to global ocean carbonate production, J. Eukaryot. Microbiol., 55, 163-169, https://doi.org/10.1111/j.1550-7408.2008.00321.x, 2008.

Langer, M. R. and Gehring, C. A.: Bacteria farming; a possible feeding strategy of some smaller motile Foraminifera, J. Foraminifer. Res., 23, 40-46, https://doi.org/10.2113/gsjfr.23.1.40, 1993.

Langer, M. R. and Mouanga, G. H.: Invasion of amphisteginid foraminifera in the Adriatic Sea, Biol. Invasions, 18, 1335-1349, https://doi.org/10.1007/s10530-016-1070-0, 2016.

Langer, M. R., Silk, M. T., and Lipps, J. H.: Global ocean carbonate and carbon dioxide production: The role of reef foraminifera, $\mathrm{J}$. Foraminifer. Res., 27, 271-277, 1997.

Langer, M. R., Weinmann, A. E., Lötters, S., and Rödder, D.: "Strangers" in paradise: modeling the biogeographic range expansion of the foraminifera Amphistegina in the Mediterranean Sea, J. Foraminifer. Res., 42, 234-244, 2012.

Langer, M. R., Weinmann, A. E., Lötters, S., Bernhard, J. M., and Rödder, D.: Climate-Driven Range Extension of Amphistegina (Protista, Foraminiferida): Models of Current and Predicted Future Ranges, PLoS One, 8, e54443, https://doi.org/10.1371/journal.pone.0054443, 2013.
Lee, J. J. and Anderson, R. O. (Eds.): Symbiosis in Foraminifera, in: Biology of Foraminifera, Academic Press, London, 157-220, 1991.

Lipps, J. H.: Biotic interactions in benthic Foraminifera, Biotic Interactions in Recent and Fossil Benthic Communities, 331-376, https://doi.org/10.1007/978-1-4757-0740-3_8, 1983.

Lukešová, T., Kohout, P., Větrovský, T., and Vohník, M.: The potential of dark septate endophytes to form root symbioses with ectomycorrhizal and ericoid mycorrhizal middle european forest plants, PLoS One, 10, e0124752, https://doi.org/10.1371/journal.pone.0124752, 2015.

Malumián, N., Cabrera, M. I. L., Náñez, C., and Olivero, E. B.: Bioerosion patterns in cretaceous-cenozoic benthic foraminiferal tests from Patagonia and Tierra del Fuego Island, Argentina, SEPM Spec. Publ., 88, 301-308, https://doi.org/10.2110/pec.07.88.0301, 2007.

Martin, R. E.: Taphonomy and temporal resolution of foraminiferal assemblages, in: Modern Foraminifera, edited by: Sen Gupta, B. K., Kluwer Academic Publishers, New York, 281-298, 1999.

Martin, R. E. and Wright, R. C.: Information loss in the transition from life to death assemblages of foraminifera in back reef environments, Key Largo, Florida, J. Paleontol., 62, 399-410, https://doi.org/10.1017/s002233600001831x, 1988.

Murray, J. W.: Ecology and applications of benthic foraminifera, Cambridge University Press, 2006.

Murray, J. W. and Alve, E.: Natural dissolution of modern shallow water benthic foraminifera: Taphonomic effects on the palaeoecological record, Palaeogeogr. Palaeoclimatol. Palaeoecol., 146, 195-209, https://doi.org/10.1016/S0031-0182(98)00132-1, 1999.

Neumann, A. C.: Observations on coastal erosion in Bermuda and measurements of the boring rate of the sponge Cliona lampa, Limnol. Oceanogr., 11, 92-108, https://doi.org/10.4319/lo.1966.11.1.0092, 1966.

Neumann, A. C.: Foreword, in: Current Developments in Bioerosion, edited by: Wisshak, M. and Tapanila, L., Springer Berlin Heidelberg, Berlin, Heidelberg, V-IX, https://doi.org/10.1007/978-3-540-77598-0, 2008.

Nguyen, T. M. P., Petrizzo, M. R., and Speijer, R. P.: Experimental dissolution of a fossil foraminiferal assemblage (PaleoceneEocene Thermal Maximum, Dababiya, Egypt): Implications for paleoenvironmental reconstructions, Mar. Micropaleontol., 73, 241-258, https://doi.org/10.1016/j.marmicro.2009.10.005, 2009.

Nielsen, K. S. S. and Nielsen, J. K.: Bioerosion in Pliocene to late Holocene tests of benthic and planktonic foraminiferans, with a revision of the ichnogenera Oichnus and Tremichnus, Ichnos, 8, 99-116, https://doi.org/10.1080/10420940109380178, 2001.

Perkins, R. D. and Halsey, S. D.: Geologic significance of microboring fungi and algae in Carolina shelf sediments, J. Sediment. Res., 41, 843-853, https://doi.org/10.1306/74D723792B21-11D7-8648000102C1865D, 1971.

Rämä, T., Nordén, J., Davey, M. L., Mathiassen, G. H., Spatafora, J. W., and Kauserud, H.: Fungi ahoy! Diversity on marine wooden substrata in the high North, Fungal Ecol., 8, 46-58, https://doi.org/10.1016/j.funeco.2013.12.002, 2014.

Sauvageau, M. C.: Contribution a l'étude du système mécanique dans la racine des plantes aquatiques les Zostera, Cymodocea et Posidonia, J. Bot., 3, 169-181, 1889. 
Schönberg, C. H. L. and Wisshak, M.: Marine Bioerosion, in: The Mediterranean Sea, edited by: Goffredo, S. and Dubinsky, Z., Springer Netherlands, Dordrecht, 449-461, 2014.

Serrano, O., Mateo, M. A., Renom, P., and Julià, R.: Characterization of soils beneath a Posidonia oceanica meadow, Geoderma, 185-186, 26-36, https://doi.org/10.1016/j.geoderma.2012.03.020, 2012.

Shroba, C. S.: Taphonomic features of benthic foraminifera in a temperate setting: experimental and field observations on the role of abrasion, solution and microboring in the destruction of foraminiferal tests, Palaios, 8, 250-266, https://doi.org/10.2307/3515148, 1993.

Tapanila, L.: The endolithic guild: an ecological framework for residential cavities in hard substrates, in: Current Developments in Bioerosion, edited by: Wisshak, M. and Tapanila, L., Springer Berlin Heidelberg, 3-20, 2008.

Thompson, J. D., Higgins, D. G., and Gibson, T. J.: CLUSTAL W: improving the sensitivity of progressive multiple sequence alignment through sequence weighting, position-specific gap penalties and weight matrix choice, Nucleic Acids Res., 22, 46734680, https://doi.org/10.1093/nar/22.22.4673, 1994.

Tokura, R.: Marine Fungi with Ascocarps attached to Grains of Sand from Japanese Beaches II. Kyushu and Nansei Islands, Bull. Kyoto Univ. Educ. Ser. B, 62, 27-35, 1983.

Tribollet, A., Radtke, G., and Golubic, S.: Bioerosion, in: Encyclopedia of Geobiology, edited by: Reitner, J. and Thiel, V., Springer, Dordrecht, 117-134, 2011.

Vandenkoornhuyse, P., Baldauf, S. L., Leyval, C., Straczek, J., and Young, J. P. W.: Extensive fungal diversity in plant roots, Science, 295, 2051, https://doi.org/10.1126/science.295.5562.2051, 2002.

Vohník, M.: Ericoid mycorrhizal symbiosis: theoretical background and methods for its comprehensive investigation, Mycorrhiza, 30, 671-695, https://doi.org/10.1007/s00572-020-00989$1,2020$.

Vohník, M., Burdíková, Z., Albrechtová, J., and Vosátka, M.: Testate amoebae (Arcellinida and Euglyphida) vs. Ericoid mycorrhizal and DSE fungi: A possible novel interaction in the mycorrhizosphere of ericaceous plants?, Microb. Ecol., 57, 203-214, https://doi.org/10.1007/s00248-008-9402-y, 2009.

Vohník, M., Burdíková, Z., Vyhnal, A., and Koukol, O.: Interactions Between Testate Amoebae and Saprotrophic Microfungi in a Scots Pine Litter Microcosm, Microb. Ecol., 61, 660-668, https://doi.org/10.1007/s00248-010-9777-4, 2011.

Vohník, M., Borovec, O., Župan, I., Vondrášek, D., Petrtýl, M., and Sudová, R.: Anatomically and morphologically unique dark septate endophytic association in the roots of the Mediterranean endemic seagrass Posidonia oceanica, Mycorrhiza, 25, 663-672, https://doi.org/10.1007/s00572-015-0642-7, 2015.

Vohník, M., Borovec, O., and Kolařík, M.: Communities of Cultivable Root Mycobionts of the Seagrass Posidonia oceanica in the Northwest Mediterranean Sea Are Dominated by a Hitherto Undescribed Pleosporalean Dark Septate Endophyte, Microb. Ecol., 71, 442-451, https://doi.org/10.1007/s00248-015-0640-5, 2016.
Vohník, M., Borovec, O., Župan, I., Kolařík, M., and Sudová, R.: Fungal root symbionts of the seagrass Posidonia oceanica in the central Adriatic Sea revealed by microscopy, culturing and 454-pyrosequencing, Mar. Ecol. Prog. Ser., 583, 107-120, https://doi.org/10.3354/meps12337, 2017.

Vohník, M., Borovec, O., Kolaříková, Z., Sudová, R., and Réblová, M.: Extensive sampling and high-throughput sequencing reveal Posidoniomyces atricolor gen. et sp. nov. (Aigialaceae, Pleosporales) as the dominant root mycobiont of the dominant Mediterranean seagrass Posidonia oceanica, MycoKeys, 55, 59-86, https://doi.org/10.3897/mycokeys.55.35682, 2019.

Volkmann-Kohlmeyer, B. and Kohlmeyer, J.: Biogeographic Observations on Pacific Marine Fungi, Mycologia, 85, 337-346, https://doi.org/10.1080/00275514.1993.12026282, 1993.

Walton, W. R.: Techniques for recognition of living foraminifera, Contrib. from Cushman Found. Foraminifer. Res., 3, 56-60, 1952.

Warme, J. E.: Borings As Trace Fossils, and the Processes of Marine Bioerosion, Study Trace Foss., 181-227, https://doi.org/10.1007/978-3-642-65923-2_11, 1975.

Weinmann, A. E., Rödder, D., Lötters, S., and Langer, M. R.: Heading for New Shores: Projecting Marine Distribution Ranges of Selected Larger Foraminifera, edited by A. Andrew, PLoS One, 8, e62182, https://doi.org/10.1371/journal.pone.0062182, 2013a.

Weinmann, A. E., Rödder, D., Lötters, S., and Langer, M. R.: Traveling through time: The past, present and future biogeographic range of the invasive foraminifera Amphistegina spp. in the Mediterranean Sea, Mar. Micropaleontol., 105, 30-39, https://doi.org/10.1016/j.marmicro.2013.10.002, 2013b.

Wisshak, M. and Tapanila, L. (Eds.): Current Developments in Bioerosion, Springer Berlin Heidelberg, Berlin, Heidelberg, https://doi.org/10.1007/978-3-540-77598-0, 2008.

Yokeş, M. B. and Meriç, E.: Drowning in the sand: Invasion by Foraminifera, in: Invasive species: Detection, impact and control, edited by: Wilcox, C. P. and Turpin, R. B., Nova Science Publishers, Hauppauge, USA, 7-20, 2009.

Yokeş, M. B., Meriç, E., and Avsar, N.: On the Presence of alien foraminifera Amphistegina lobifera Larsen on the coasts of the Maltese Islands, Aquat. Invasions, 2, 439-441, https://doi.org/10.3391/ai.2007.2.4.15, 2007.

Yokeş, M. B., Meriç, E., Avşar, N., Öncel, M. S., Eryilmaz, M., and Barut, I.: The expanded population of Amphistegina lobifera at Üç Adalar and Beş Adalar (Antalya, Turkey), Mar. Biodivers. Rec., 7, 1-10, https://doi.org/10.1017/S175526721400044X, 2014.

Zenetos, A., Meric, E., Verlaque, M., Galli, P., Boudouresque, C. F., Giangrande, A., Cinar, M. E., and Bilecenoglu, M.: Additions to the annotated list of marine alien biota in the Mediterranean with special emphasis on Foraminifera and Parasites, Mediterr. Mar. Sci., 9, 119-166, https://doi.org/10.12681/mms.146, 2008. 